\title{
Learning Module Design Writing Argumentative Text Based Problem-Based Learning
}

\author{
Syahrul Ramadhan, Yasnur Asri, Vivi Indriyani \\ Universitas Negeri Padang \\ Syahrul810@yahoo.com
}

\begin{abstract}
Based on the needs analysis, it is important to develop the learning module of writing the text of the argument. The modules are based on Problem Based Learning (PBL). The type of research was $R \& D$ (research \& development). The development model used is 4-D (define, design, develop, and dessiminate). In this paper, the results of the study discussed about the design of learning modules developed. By understanding the design, the reader can make this design as a guide for developing Indonesian learning module on the argument text or other text using Problem Based Learning (PBL) basis.
\end{abstract}

Keywords-design; module; writing; argument text; problem based learning

\section{INTRODUCTION}

Language plays an important role in human life. Language can develop intellectual intelligence, emotional, and spiritual intelligence (Arief, 2017). Students' language skills in Indonesia need to be improved, especially for writing skills. Writing skills is the most difficult language skills, but its role in human life is very important (Arief, 2017).

The skills developed in this study are the skill of writing argument text. Skills defined as a broad set of knowledge, skills, work habits, and characters are believed to be critical to future success (Rotherham \& Willingham, 2000). Skills are needed to solve complex problems, collaborate and communicate well with others, gain skills and information independently, and can adapt to rapidly changing conditions to compete globally at the present time (Gewertz, 2008).

Based on the data obtained, the skills of Bahasa Indonesia especially reading and writing need to be improved. It can be seen based on the following data. First, based on the PISA (Programe for International Student Assessment) data, by 2015, Indonesia ranks 64th out of 70 countries evaluated (OECD, 2016). Secondly, based on the PIRLS (Program in International Reading Literacy Study) data in 2011 Indonesia ranks 45th out of 48 countries evaluated (IEA, 2012). Third, Indonesia ranks second lowest in reading interest based on a survey from UNESCO (UNESCO, 2016). Fourth, the value of Indonesian Language Examination in 2017 decreased from the previous year (Republika, 2017).

Learning Indonesian is a text-based learning (Mahsun, 2014). One type of text students learn in Senior High School (SMA) is an argument text. Writing argument texts is a standard curricular topic in schools because it is critical for critical thinking and academic success (Hillocks, 2011).

Andrews (2009) states that 'arguments' and 'arguments' are often used interchangeably. Though the two terms have differences. Arguments are a more general term that refers to a product or manifestation of arguments, such as debates, essays, research papers, and is also used for a wider range in verbal, written, and other modes. Arguments are part of an argument that refers to something more technical. Argumentation is the process of debating in education, politics, business, law, and other contexts.

Arguments are essential in everyday life, because almost all work or all things require argument (Syaifudin \& Pratama, 2013). Arguments have a major role in developing, evaluating, and validating knowledge (Duschl \& Osborne, 2002). In addition, arguments can serve to control the compatibility of opinions with evidence or phenomena (Wijaya, Rahayu, \& Agustini, 2017).

Andrews (2009) states that arguments are very important in education because of the following points. First, it is important to argue rationally in a civilized society and students (higher education level) are expected to do so both in school and in the real world. Second, advances in knowledge often come through arguments. Third, the argument is about classification and persuasiveness. Fourth, arguments can be fun.

Newell et al (2011) suggests that learning to write texts argues defiantly for the following reasons. First, the argument text learning is complex. Secondly, the students have no audience other than the teaching teacher. Third, the argument text learning does not fit the learning approach. Fourth, teachers may be less experienced in dealing with complexity.

It's hard to teach a good argument (Andrews, 2009). Even some countries assess teachers' ability to build student arguments to achieve certification (Harris, 2014). Building arguments is also seen as an active and effective element of citizenship (Howell, Butler \& Reinking, 2017). Teaching students to write effective argument texts has been identified as an instructional challenge (Howell, Butler \& Reinking, 2017). The teacher needs to design a case of thought or 
problem (Liu, 2016). Hillocks (2010) states that writing argument texts requires complex logical reasoning outside of persuasive writing.

To overcome this, the development of learning modules is one of the solutions to assist teachers in teaching (Roselina, 2014; Andayani, Pratiwi and Priyatni, 2017). According to Prastowo (2012) the module is basically a teaching material that is arranged systematically with language that is easily understood by the students according to the level of knowledge and age, so that can be studied independently with a little help of educator. Learning module is a teaching material designed by the teacher. By designing the module, teachers can prepare the learning maturely so that the learning objectives can be achieved.

In line with the opinion of Kharade \& Peese (2014) that language learning is a complex process with the intellectual, social and emotional dimension. Therefore, teaching any language is a multidimensional activity. Language learning should be designed by subject teachers tailored to the national, regional, and foreign language teaching curriculum according to the educational context. So that multidimensional activities can be realized.

The learning module of writing argumented text is developed based on problem based learning (PBL). The concept of PBL is in line with a scientific approach and text-based learning. Thus, the PBL used as the basis for the development of this module requires learning to write argumentary text that can be done independently with the steps and conditions that have been established.

The selection of PBL as a learning module base was motivated by research conducted by previous researchers (Wiggins \& Burns, 2001; Donnelly, 2003; Kharade \& Peese, 2014; Dastgeer \& Afzal, 2015; Liu, 2016; Yin, 2017). The reasons for using PBL as a learning module base are developed for the following reasons. First, problem-based learning (PBL) has been successfully used in many disciplines for more than 30 years (Kim, 2014). Secondly, PBL is particularly suitable for student-centered learning and offers some advantages in student-centered classrooms (Driessen \& Vleuten, 2000). Third, PBL is an engaging instrumental strategy that directs students to active and independent learning and enables students to learn to solve problems (Kim, 2014).

Fourth, PBL excels in terms of long-term retention, development skills, and student and teacher satisfaction (Stobel and Barnevelt, 2009). Fifth, the PBL has a positive impact on problem solving (Kharade \& Peese, 2014). Sixth, PBL can assess the ability of learners (Dochy et al., 2003). Seventh, PBLs can enhance students' sense of participationstudents who do not like to talk have opportunities-in class activities, so the interaction between teachers and students, or even among students becomes meaningful.

As one of the best exemplars of student-centered learning, problem-based learning (PBL) was developed in medical education in 1970 and has evolved into various disciplines at various levels of education (Donnelly, 2003; Savery, 2006; Stedmon, 2006 ; Kharade \& Peese, 2014; Kim, 2014). PBL is an effective tool to encourage students to develop critical and creative skills, and enhance their learning innovation skills through problem-solving (Sun, 2017).

PBL is an instructional approach based on many constructivist learning principles and theories, which see students as active learners and build knowledge through interaction with the environment and social negotiations (Kharade \& Peese, 2014). Constructivism also means that learning is as important as what is learned (Savin-Baden, 2004). PBL refers to a student-centered curriculum that empowers students to conduct research and requires students to learn a range of knowledge and skills while solving real problems in relevant and authentic contexts (Donnelly, 2003; Savery, 2006).

Barrows (2002) describes in detail four key elements of PBL learning. First, unstructured problems are presented to students by generating some potential causes of problems and solutions through various questions. According to Ge and Land (2004), unstructured problems are defined as problems encountered in everyday life, where one or more aspects of a situation are not well defined, objectives are unclear, and there is not enough information to solve problem. Second, students have responsibility for their own learning. They decide what to do when learning and find the right information to solve problems from various resources, such as libraries, online, experts, and textbooks (Kim, 2014). Third, the teacher acts as a facilitator in the learning process (Dahlgren, 2000; Wiggins \& Burns, 2009; Kharade \& Peese, 2014). Fourth, the results of the learning should be relevant to the student's learning.

There are three main principles of PBL (Dahlgren \& Dahlgren, 2002; Hmelo-Silver, 2004). First, real life scenarios are used to apply contextual learning. Second, knowledge is built through interaction in peer group discussions. Third, students engage in self-learning and become more aware of the metacognitive processes involved in learning.

According to Liu (2016), the advantages of PBL as a base in learning are as follows. First, Increase student interest and motivation in learning. Second, students can understand learning well rather than using traditional learning. Third, it contributes to the cultivation of students' comprehensive skills such as cooperation, investigation, problem solving and critical thinking that are useful not when learning, but also useful in the workplace. Fourth, help facilitate teacher role shifts and be conducive to classroom teaching innovation.

Problem Based Learning (PBL) used as the basis for compiling this learning module is organized on five steps. The five steps include, student orientation on issues, organizing students to learn, guiding individual and group investigations, developing and presenting the work, analyzing and evaluating the problem-solving process (Hosnan, 
2014). Therefore, the five steps are used as the foundation in preparing the learning module of writing the text of the argument.

Based on the reality, it is important to develop teaching materials in the form of learning module of writing problem based learning (PBL) in class $\mathrm{X}$ high school. With the presentation of materials and steps of structured activities, students are expected to more quickly get the concept and able to write the text with good. The learning module is expected to provide solutions for students who find it difficult to write an argumentary text and help teachers in the learning process. This module is also expected to develop students' creativity and innovation in learning.

Based on the background, the purpose of this study is to explain the design of learning module of writing text based on problem based learning. This research journal focuses on the design of learning modules that aim to explain the learning steps presented in the module so that readers can understand and develop their own learning modules as one of the learning resources.

\section{METHODS}

The type of research used in this study was research development. Research development was a research method used to produce a specific product and test the effectiveness of the product (Sugiyono, 2010). The result of this research was in the form of learning-based text writing module based on Problem Based Learning (PBL).

The module development process was carried out following the 4-D model was suggested by Thiagarajan, et. al. (in Trianto 2012). The 4-D model consists of four development stages: define, design, develop, and disseminate. The types of data in this study were quantitative data and qualitative data. Data were obtained through questionnaires, interviews, observation sheets, and tests. In this paper, the results of the research would be discussed in the design section of the learning module.

In the development research, product development was the main thing. Products that had been developed, further validated and tested. Trial was conducted for high school in Padang to get practicality and effectiveness value. For the test results, it could be seen in my other research journals.

\section{FINDING AND DISCUSSION}

The results of this study are based on the design stage of the development research stage. This research phase was carried out following the 4-D model suggested by Thiagarajan, et. al. (in Trianto 2012). The 4-D model consists of four development stages, namely define, design, develop, and disseminate. The results of the study are as follows.

\section{Define}

The analysis in the defining stage is done with five stages, namely the beginning-end analysis, student analysis, concept analysis, curriculum analysis, and objective formulation analysis. With the help of research instruments in the form of interview sheets, questionnaires, and observation sheets done in schools with the participation of teachers and students to obtain data, it can be concluded that it is important to develop the learning module as a solution to problems in language learning. The analysis results of the general definition stage can be seen in the following table.

Table 1. Results of the Definition Stages Analysis

\begin{tabular}{ll}
\hline \multicolumn{1}{c}{ Definition Stages } & \multicolumn{1}{c}{ Analysis Results } \\
\hline Needs Analysis & The learning resources used by the students are limited. \\
\hline Students Analysis & $\begin{array}{l}\text { Students who are the subjects of research are high school X students aged around 15- } \\
16 \text { years. }\end{array}$ \\
\hline Concept Analysis & The text argues for three texts, the exposition text, the debate text, and review text. \\
\hline Curriculum Analysis & Curriculum 2013 revised edition 2017 \\
\hline $\begin{array}{l}\text { Objective Formulation } \\
\text { Analysis }\end{array}$ & Students are able to write argumentary text \\
\hline
\end{tabular}

\section{Design}

After the needs analysis, the learning module is then designed. The design of the module structure is developed in accordance with the opinions expressed by Daryanto and Dwicahyono (2014), which consists of three main parts, namely introduction, learning and evaluation. However, before that section, there will be a cover page, introduction, table of contents, module position map. Then, at the end of the module is a reference list. The description of the components of the module is as follows.

a. Introduction Module

Introduction is an introductory part of the learning module that contains several aspects that serve to provide an initial explanation of the contents of the module. The module is one of the teaching materials that aims to enable students to learn independently. The module introductory section works so that students can understand the module's use without having to hear the teacher's detailed explanation. This section contains several aspects that vary according 
to the module designer. The module introduction aspect is flexible and adapted to the students' needs so that the learning objectives using the module are well executed.

The contents of the module framework in the introductory section designed in this study are as follows. (a) Core Competencies and Basic Competencies to serve as a reference for the lessons learned. (b) Prerequisites, conditions that must be met before studying the module. (c) Orientation, explanation of important points learned by students. (d) Time, The amount of time it takes to learn the module. (e) Module usage instructions.

\section{b. Learning Activities}

Learning activities are the most important part of the learning module. Learning activities in the module aims to have students knowledge and skills. The knowledge is gained by understanding the description of the material described in the module. Skills are obtained by practicing in order to have language competence, one of which is writing text.

In addition to the description of learning materials that are an important element in the learning activities, in this section there are also some aspects that support the learning activities. The contents of the module framework in this section contain Basic Competencies, indicators, learning objectives, learning benefits, material descriptions, conclusions, summaries, exercises, and self-assessment. Section of supporting aspects of this learning activity can be adjusted to the needs of students.

Learning activities on modules that are designed more meaningful because developed based on Problem Based Learning (PBL) learning model. The PBL used as the basis for developing this learning module is organized on five steps. The five steps include student orientation on issues, organizing students for learning, guiding individual and group investigations, developing and presenting the work, analyzing and evaluating the problem-solving process. Explanation of the steps of learning activities in the learning module are described below.

1) Student Orientation on Problems

Student orientation to the problem is an early stage in PBL-based learning activities. In the learning module, students are directed to read some of the issues that occur at this time. The issue should be tailored to the students' understanding. Learning activities are based on problems, where teachers choose various issues for students to learn (Iversen, Pedersen, Krogh \& Jensen, 2015). In this module there are three issues that aim to enable students to express their opinions on the issues they have read. The activity is done because the lesson is the argument text, so that the students are able to argue based on the issue.

Issues featured in the modules developed in this study include harassment, fake news, social media addiction, and online game addiction. Selection of the issue is based on the context around students. It is in line with the PBL principle that real life scenarios are used to apply contextual learning (Hmelo-Silver, 2004).This stage for learning Indonesian language using PBL based learning module for each text is different. For learning the argument text can use the design described. However, if developing a PBL-based learning module with other text types, such as procedural texts, story texts, news texts, etc., should be tailored to the text. The designs in this section can be almost identical or completely different.

2) Organizing Students to Learn

This stage is done to guide students find their own concept of writing the text arguing independently. This section has examples of argumentable text that students can read. After reading the text, students are expected to be able to know one type of text, the text argued. In this section there is a detailed learning material on the texts being studied. The learning material consists of the essence of the texts being studied (argument), meaning, function, purpose, structure and the linguistic features of the text.

In this section there are also worksheets to test students' knowledge of the material they have read. Before working on the worksheet, students read an argument text. Based on the text that has been read, students determine the structure of the text by writing the structure and paragraph number of the text structure that has been read. The next worksheet is students looking for words/phrases/ clauses/phrases that characterize the language of the argument text.

This stage for Indonesian language learning uses PBL-based learning modules for each text alike. However, for student exercises or worksheets can be tailored to the module maker (teacher/researcher). This section is better to prioritize the wealth of teaching materials to increase student knowledge, while for practice/worksheets, can be maximized in the next step.

3) Guiding Individual and Group Investigations

This stage aims to encourage students to solve problems through group discussion and individual thinking. In groups, students organize prior knowledge, attempt to define the nature of the problem, design problem-solving, and identify the resources needed (Donnelly, 2003; Stedmon, 2006).

In the learning module, students with a group are asked their opinion on a case (in the module, the case discussed is about excessive posting). The group's opinion, written in paragraph form. Furthermore, students are asked to look for some arguments from various sources to serve as arguments in support of student opinions. Information can be found in libraries, online, experts and textbooks (Barrows, 2002). Furthermore, students are asked to write suggestions on the issues discussed. 
This stage for learning Indonesian language using PBL based learning module for each text is different. For learning the argument text can use the design described. However, if developing a PBL-based learning module with other text types, such as procedural texts, story texts, news texts, etc., should be tailored to the text. The designs in this section can be almost identical or completely different.

4) Developing and Presenting Results of Work

This stage is done by guiding students to prepare the work after studying the material and practice to write the text of the argument. The results of group investigations that have been done, collected, and organized into a good text of argument. Good-argument text is a text that corresponds to the structure and characteristics of the language of the text. The student's work is in the form of argument text.

This stage for learning Indonesian language using PBL-based learning modules for each of these texts is the same. It is adapted to the competence and learning objectives achieved that students are able to write text. However, to accompany students to be able to present the work on each different text, tailored to the type of text to be written.

5) Analyze and Evaluate Problem Solving Processes

This stage is done to encourage students to work together and share learning experiences with other students. The module presented guides students to reflect on their investigations and processes in finding solutions to problems, for example by asking what concepts are used to solve the problem.

c. Evaluation of the Module

The module evaluation is the final part of the learning module. this section can also serve as an assessment. For learning writing, assessment can be done by performing performance tests. The test framework was modified from Atmazaki (2017) opinion, which designed the performance test consisting of three parts, namely the context, instruction, and assessment rubric. By reading and understanding the sections, students are expected to be able to do the test without waiting for an explanation from the teacher. The evaluations contained in the learning module have additional components such as answer sheets and assessment guides. These components work so that students can judge for themselves the text that has been written, so that the assessment is done in a transparent manner.

2. Develop

The development phase is the stage that is carried out after the product being developed has been designed. The activities carried out are validation and testing. The results of the study showed that the text-writing learning module that generated PBL-based arguments was valid, practical, and effective. This is evidenced by the results of the validity, practicality, and effectiveness of the module.

The validity of the module by the expert is obtained based on the module validity value of $83.41 \%$ so that the module is very valid in the category. Module practicality is obtained based on the teacher's practicality value of $94.56 \%$ with a very practical category and student practicality of $82.48 \%$ with a very practical category. Student learning activities obtain a value of $90.92 \%$. with the category of active activists. The effectiveness of the module is based on the results of the student performance test the average value obtained by students is 88 with the predicate A. The effectiveness of the module based on student knowledge the average value obtained by students is 88.7 with a predicate A. Effectiveness of modules based on assessment based on the value of attitude aspects obtained values equal to 92.6 with predicate A and character 93.6. with an A title so that it is very effective.

3. Disseminate

The disseminate phase is the last stage in development research using a 4-D development model. This stage is an activity to disseminate the products developed. This is done by making lots of products and distributing them to students and teachers. the dissemination carried out in this study was limited to research school students.

The design of the learning module is the most fundamental activity in the development research. Instead of elaborating on the results of the test, this paper focuses more on the contents of the developed learning module design. The learning module was developed for various factors. One of them is required of teaching materials in accordance with the needs and environment of students.

Lesson books used have been able to support to achieve the learning objectives, but the need for science makes students try to find information from various sources. One learning resource that is able to support learning is a learning module developed by the teacher. In addition to increasing the knowledge of students, the learning module is also able to train students to be skilled by learning independently. In addition, teachers are also helped in the learning process.

The learning module developed is an Indonesian language learning module to write an argumented text. The argument text studied in the module consists of three texts, the exposition text, the text of the debate, and the text of the overview. This is because writing argument texts is a standard curricular topic in schools because it is critical to critical thinking and academic success (Hillocks, 2011). In addition, it was also found that the writing skill of students is still below the standard of completeness. It is also in accordance with the opinion of Andrews (2009) that a good argument in conversation, conversation, discussion, or debate does not always move into writing good arguments, and vice versa.

Learning module developed based on Problem Based Learning (PBL). Selection of the learning model because PBL is a basic learning problem, it is in accordance with the essence of the text of the argument that an argument exists because of an issue or problem. In accordance with the opinion of Newell et. al (2011), that the learning of writing the 
test argues challenging because the study of the text of the argument does not match the learning approach used. Having the same nature, PBL is indicated capable of helping students to be able to write argument text.

After the learning module is completed, the module is validated by several experts. The validated module is valid, then the module is tested in the school to know the value of practicality and the effectiveness of the module designed. For these results, will be explained in the next paper.

\section{CONCLUSION}

Based on the results of research and discussion can be concluded that the learning module can be used as additional teaching materials for learning Indonesian language writing the text beragumen. The learning module can be developed by teachers who are adapted to the needs of the students.

By understanding the learning module that has been described, this paper is expected to be a good reference for subject teachers, subsequent researchers, and educational community, to be able to design their own learning modules needed for learning activities. The module design described is just a model, and can be tailored to the needs of the next module designer.

\section{References}

Andayani, R. Pratiwi,Y dan Priyatni, E. T. (2017). Pengembangan modul pembelajaran menulis cerpen bermuatan motivasi berprestasi untuk siswa kelas XI SMA. BASINDO, Jurnal Kajian Bahasa, Sastra Indonesia, dan Pembelajarannya. 1(1), pp. 103-116.

Andrews, R. (2009). Argumentaton in higher education. New York: Routledge.

Arief, D. (2017). Material eriting characterized narration for elementary school. Atlantis Press, Advances in Social Science, Education and Humanities Research, 118, pp. 865-869.

Atmazaki. (2017). Authentic assesment in Indonesian language learning. Atlantis Press, Advances in Social Science, Education and Humanities Research, 148, pp. 302-309.

Barrows, H.S. (2002). Is it truly possible to have such a thing as PBL? Distance Education, Vol. 23(1), pp. 119-122.

Dahlgren, M. A. (2000). Portraits of PBL: Course objectives and students' study strategies in computer engineering, psichology and physiotherapy. Intructional Science, 28(4), pp. 309-329.

Dahlgren, M. A. \& Dahlgren, L. O. (2002). Portaits of PBL: Students' experience of the characteristics of PBL in physiotherapy, computer engineering and psychology. Intructional Science, 30(2), pp. 111-127.

Daryanto dan Dwicahyono, A. (2014). Pengembangan perangkat pembelajaran (Silabus, RPP, PHB, Bahan Ajar). Gava Media: Yogyakarta.

Dastgeer, G. dan Afzal, M. T. (2015). Improving english writing skill: a case of problem based learning. American Journal of Educational Research, 3(10), pp. 1315-1319.

Dochy, F. Et al. (2003). Effects of problem based learning: a meta analysis. Learning and Instruction, 13(5), pp. 533568 .

Donnelly, R. (2003). Using problem-based learning to explore qualitative research. European Educational Research Journal, 2(2), pp. 209-321.

Drissen, E. \& Vleuten, C. V. D. (2000). Matching student assessment to problem based learning: Lesson from experience in law faculty. Studies in Continuing Education, 22, pp. 235-248.

Duschl, R. \& Osborne, J. (2002). Supporting and promoting discourse argumentation in science education. Studies in Science Education, 38(1), pp. 39-72.

Ge, X. \& Land, S. M. (2004). A conceptual framework for scaffolding ill-structures problem solving processes using question prompts and peer interactions. Educational Technology Research \& Development, 52(2), pp. 5-22.

Gewertz, C. (2008). States press ahead on 21st century skill. Education Week, 28(8), pp. $21-23$.

Harris, E. A. (2014). Passing rate declines by $20 \%$ as state uses new certification exams for teachers. New York Times, access 2018, May 28.

Hillocks, G. (2010). Teaching argument for critical thinking and writting: An introduction. English Journal, 99(6), pp. $24-32$.

Hillocks, G. (2011). Preface. In Teaching argument writting: Supporting claims with relevant evidence and clear reasoning (pp. Xv-xxvi). Postsmount, NH: Heinemann.

Hmelo-Silver, C. E. (2004). Problem based learning: What and how do students lear? Educational Psychology Review, 16(3), pp. 235-266.

Howell, E., Butler, T. \& Reinking, D. (2017). Integrating multimodal arguments into high school writing instruction. Journal of Literacy Research, 49(2), pp. 181-209.

Hosnan. (2014). Pendekatan saintifik dan kontekstual dalam pembelajaran abad 21. Ghalia: Bogor.

Iversen, A., Pedersen, A. S., Krogh, L. \& Jensen, A. A. (2015). Learning, leading, and letting go of control: Learner-led approaches in education. Sage Open, pp. 1-11. 
Kharade, K. \& Peese, H. (2014). Problem-based learning: a promising pathway for empowering pre-service teachers for ICT-mediated language teaching. Policy Futures in Education, 12(2), pp. 262-272.

Kim, D. Y. (2014). Adopting problem based learning in criminology and criminal justice education: Challenge and response. Sage Open, pp. 1-13.

Liu, Q. (2016). Enchancing college oral english teaching with application of PBL. Atlantis Press, International Conference on Arts, Design and Contempory Education, pp. 1485-1489.

Mahsun. (2014). Teks dalam pembelajaran bahasa Indonesia kurikulum 2013. Rajawali Pers, Jakarta.

Newell, G. E. et al. (2011). Teaching and learning argumentative reading and writting: A review of research. Reading Research Quarterly, 46(3), pp. 273-304.

OECD. 2016. "PISA 2015 results in focus", (Online), (http://www.oecd.org/ pisa/pisa-2015-results-in-focus.pdf, diakeses tanggal 25 Maret 2018).

IEA. (2011). International Report. Performance at the PIRLS 2011. International Benchmarks TIMMS \& PIRLS Report International Study Center (IEA): Lynch School of Education, Boston College.

Prastowo, A. (2012). Panduan reatif membuat bahan ajar inovatif: Menciptakan metode pembelajaran yang menarik dan menyenangkan. Yogyakarta: Diva Press.

Republika. (2017). "Nilai UN bahasa Indonesia dan bahasa Inggris anjlok.” www. Republika.co.id (diakses 25 Maret 2018).

Roselina. (2014). Pengembangan modul pembelajaran menulis puisi berdasarkan pendekatan stilistik untuk Siswa SMA. Lingua, Jurnal Bahasa \& Sastra, 15, No. 1, pp. 44-53.

Rotherham, A. \& Willingham, D. (2009). 21st century skills: The challenges ahead. Education Leadership, 67, pp. 1621.

Savery, J. R. (2006). Overview of problem-based learning: Definitions and distinctions. The Interdisiplinary Journal of Probelm-Based Learning, 1 (1), pp. 9-20.

Savin-Based, M. (2004). Understanding the impact of assessment on students in problem-based learning. Innovations in Education and Teaching International, 41(2), pp. 223-233.

Stedmon, J. (2006). Development of PBL in the training of clinical psychologists. Psychology Learning and Teaching, $5(1)$, pp. $52-60$.

Strobel, J. \& Barnevelt, A. (2009). When is PBL more effective? A meta-synthesis of meta-analyses comparing PBL to conventional classrooms. The Interdisciplinary Journal of Broblem Based Learning, 3 (1), pp.44-58.

Sun, K. \& Li, Z. Y. (2017). A discussion on the differences between problem based learning and project based learning. Atlantis Press, Advances in Social Science, Education and Humanities Research (ASSEHR), 83, pp. $229-234$.

Sugiyono. (2010). Metode penelitian pendidikan pendekatan kuantitatif, kualitatif dan $R$ \& D. Bandung: Sinar Baru.

Syaifudin, A. \& Pratama, H. (2013). Pengembangan buku teks menulis argumentasi berdasarkan pola penalaran argumentatif. Jurnal Penelitian Pendidikan, 30 (1), pp. 1-10.

UNESCO. (2015). Literacy. http://www.unesco.org/new/en/education/themes/ education-buildingblocks/ literacy/ (Diakses 25 Maret 2018).

Wiggins, S. \& Burns, V. (2009). Research methods in practice: The development of problem-based learning materials for teaching qualitative research methods to undergraduate students. Psycology, Learning and Teaching, 8(1), pp. $29-33$.

Wijaya, B. R., Rahayu, Y. S. \& Agustini, R. (2017). Improving students' scientific arguments guided inquiry ability through student textbook. Atlantis Press, Advances in Social Science, Education and Humanities Research (ASSEHR), 108, pp. 87-90.

Yin, W. (2017). A study on the application of collage english PBL teaching mode in the multimedia environment. Atlantis Press, Advance in Computer Research (ACSR), 76, pp. 957-960. 